\title{
How Education and Training May be Used to Increase Eco-friendly Transports
}

\author{
Lisa-Maria Putz and Oliver Schauer \\ Logistikum - Department for Transport Management \\ University of Applied Sciences Upper Austria, Austria
}

\section{lisa-maria.putz@fh-steyr.at oliver.schauer@fh-steyr.at}

\begin{abstract}
The aim of this paper is to demonstrate how education and training may be used to increase the use of eco-friendly transport modes for freight transport. Due to an increase in education and training people's awareness for the eco-friendly transport mode inland navigation should be enhanced. The results of this paper are part of the education cooperation "REWWay". Qualitative empiric research in form of expert interviews and focus groups is used to identify stakeholders' needs for education and training for eco-friendly freight transport. The research sample consists of secondary, vocational and tertiary education and the industry. Results demonstrate a lack of transport education for eco-friendly transport. Teachers, lecturers and the industry are highly interested in appropriate and high-quality offers in education and training. Moreover, results suggest that appropriate education concerning eco-friendly transport opportunities is able to support a shift towards eco-friendly logistics.
\end{abstract}

Keywords: Transport education, eco-friendly transport, qualitative empiric research, inland waterway transport, freight transport.

\section{Introduction}

Some years ago access to means of transport was limited to few wealthy groups of persons. Global competition and technical development made it possible to reduce transport prices and to enhance travelers' comfort. Nowadays, mobility is the engine which drives modern society and a substantial part of the worldwide progress. The growth in GDP and the growth in freight transport generally follow the same trends (European Union, 2013). As a consequence, during the last decades, mobility and freight transport have been increasing dramatically. Simultaneously, drastic destructive effects on ecology, economy and society have been caused (European Commission, 2011; European Union, 2013). An example for the negative impacts is the increasing number of

Material published as part of this publication, either on-line or in print, is copyrighted by the Informing Science Institute.

Permission to make digital or paper copy of part or all of these works for personal or classroom use is granted without fee provided that the copies are not made or distributed for profit or commercial advantage AND that copies 1) bear this notice in full and 2) give the full citation on the first page. It is permissible to abstract these works so long as credit is given. To copy in all other cases or to republish or to post on a server or to redistribute to lists requires specific permission and payment of a fee. Contact Publisher@InformingScience.org to request redistribution permission. urban areas which regularly exceed emission limits due to smog ("Wrapped in smog," 2013).

Nevertheless, a further worldwide increase in freight transport is expected which causes a further increase in emissions. In order to decrease negative effects of transportation, the European Union (EU) has set the goal to cut emissions for the transport sector of $60 \%$ by 2050 (Directorate General for Mobility 
and Transport, 2013). Thus, the shift to more eco-friendly modes of transport inland waterway and railway are supported as one main measure to meet emission goals by 2050 . Inland waterway and railway are considered as more eco-friendly transport modes compared to road transport since significantly lower external costs are produced (European Commission, 2011). The European Union declares inland waterway transport as the most eco-friendly transport mode compared with railway and road in Europe (Directorate General for Mobility and Transport, 2013). In fact, inland navigation provides with the lowest greenhouse gas emissions and lowest external costs. Moreover, transportation costs are very favorable (Dolinsek et al., 2013; European Commission, 2012).

Nevertheless, in $201275.1 \%$ of all transports in EU-28 were performed by truck, only $18.2 \%$ were done by railway and $6.7 \%$ by road transport (Eurostat, 2013).

One important measure to enhance inland navigation - apart from financial and governmental incentives - is to enhance knowledge concerning eco-friendly transport modes. Soft measures such as education and creating awareness for sustainable transport are needed to support the acceptance of hard measures (e.g., taxes, emission standards, fiscal rules). Since logistics students and people working within the logistics industry make transport decisions and usually people decide in favor of familiar opportunities to raise awareness on eco-friendly transport is a step factor for a modal shift. In particular, knowledge gained through education and training may be able to raise awareness for a more eco-friendly transportation and to enhance a shift to railway and inland waterway (OECD, 2004).

\section{Objectives}

The aim of this paper is to demonstrate how education and training may be used to increase the use of railway and inland waterway. Railway and inland waterway are considered as eco-friendly freight transport alternatives compared with road transport. The research questions guiding this study are: Is there a lack of education and training offers for inland waterway transport? Which training offers require educational institutions and the industry in order to increase inland waterway transport?

This contribution presents results of an education cooperation between the University of Applied Sciences Upper Austria and viadonau (state-owned company responsible for waterways in Austria) called REWWay (Research and Education in Inland Waterway Logistics). The overall aim of REWWay is to develop high-quality training and education offers to enhance the share of the most eco-friendly transport mode in Europe: inland waterway transport (Directorate General for Mobility and Transport, 2013). In order to develop stakeholder-specific offers, a broad analysis of the current situation and future requirements using qualitative empiric research was conducted.

To demonstrate these assumptions qualitative empiric research is applied. Expert interviews and focus groups are conducted and afterwards, participants' statements are analyzed by qualitative empiric methods of Mayring (2010).

\section{Methodology}

The paper reports on the authors' work on qualitative research according to the concept of qualitative social-research using a four-step process. The research was conducted in Austria since Austria has access to the three land transport modes rail, road, and inland waterway (i.e., the Danube).

First, a study to identify secondary and tertiary educational establishments which offer teaching units focusing on logistics was conducted.

Second, after educational institutions concentrating on logistics and the logistics industry were identified, and they were separated in four groups: secondary education, tertiary education, voca- 
tional schools (dual system) and the industry. Vocational schools combine ten weeks school per year with practical training at a company. This dual system takes between three to four years and ends with a diploma. To contrast the results from geography and logistics teachers an expert in didactics was invited. This person was not an expert the topic geography or logistics.

Third, representatives from the industry (i.e., logistics sector, shippers) were invited to participate in a focus group. In fact, the identification of industry's requirements is a main issue to meet the demands of the dynamic development in the logistics sector (van Hoek, 2001).

Fourth, expert interviews and focus groups with the sample groups identified in step one to three were conducted and analysed using Mayring (2010).

\section{Participants}

The research sample included six sample groups. Whereas the first part of the samples represents the industry, vocational schools, upper schools and universities which focus on logistics, the second consist of upper schools and a didactic expert without a focus on logistics.

First, education institutions which focus on logistics were identified by curricula research and interviews. Important companies in the logistics industry were identified by desktop research. In order to identify educational facilities (concentrating on logistics), criteria concerning the amount of logistic-contents are determined.

Second, representatives of these establishments were contacted and invited to participate in focus groups or in expert interviews.

Third, three focus groups (for the sample groups industry, upper school focus logistics, and universities) and expert interviews were conducted. Moreover, secondary schools were interviewed on the same topic. Finally, a didactic expert was consulted to contrast results of the first three steps. In total 39 participants from different institutions in the educational sector and the industry were included in the research sample. This total amount of identified institutions and number of participants are presented in Table 1.

Table 1 - Research Sample

\begin{tabular}{|c|c|c|}
\hline Results & $\begin{array}{c}\text { Total number } \\
\text { of institution }\end{array}$ & $\begin{array}{c}\text { Participants } \\
\text { (focus groups } \\
\text { and interview) }\end{array}$ \\
\hline $\begin{array}{c}\text { Vocational school } \\
\text { focus logistics }\end{array}$ & 3 & 3 \\
\hline $\begin{array}{c}\text { Upper school focus } \\
\text { logistics }\end{array}$ & 13 & 8 \\
\hline $\begin{array}{c}\text { Upper school } \\
\text { general }\end{array}$ & - & 10 \\
\hline $\begin{array}{c}\text { Universities } \\
\text { focus logistics }\end{array}$ & 18 & 13 \\
\hline $\begin{array}{c}\text { Logistics industry } \\
\text { Didactic expert }\end{array}$ & - & 1 \\
\hline
\end{tabular}




\section{Results \& Discussion}

The aim of this paper is to demonstrate how education and training may be used to increase the use of eco-friendly transport modes for freight transport. Results suggest that methods which require students' active learning as well as train-the-trainer

The results of this study show that few teaching units deal with the topic transport in general. Whereas most units focus on road transport only few describe and discuss eco-friendly transport modes such as inland waterway and railway. In fact, a lack of logistics peoples' knowledge and missing experiences in inland navigation and railway transport create a hurdle to enhance the share for eco-friendly transport modes. Students which represent future "decision-makers" miss awareness for this green transport alternative.

In the 70ies, logistics has started to establish as a interdisciplinary scientific field. Logistics has its origins in the military. Due to the late formation in the 70ies, logistics is a very young scientific discipline. Indeed, it took year to become from a minor subject area to a part of sciences which has been seen as equally. For years, the number of study programs offering a specialization on logistics has been increasing similarly to the number of publications on logistics. Logistics deals with a various amount of topics such as purchasing, distribution, decision support systems, transportation, IT support; resulting in a high level of interdisciplinary (Lancioni, Forman, \& Smith, 2001; Stock \& Broadus, 2006). Logistics as a scientific field is strongly characterized by its strong connection with the industry. In fact, research in logistics is intensely driven by industry and thus, very dynamic (van Hoek, 2001).

However, the dynamic requirements make up-to-date and state-of-the art contents in logistics education necessary. Since hardly any time in logistics education has been used for eco-friendly transport within the past years, education material is old-fashioned and teachers' knowledge is missing. Professors and lecturers claim for train-the-trainer offers, such as specialized trainings or books, which support them to get familiar with the topic of eco-friendly transport.

The sample group industry was questioned about the current status of knowledge in the field of inland waterway transport within their companies. In fact, the industry representatives highlight a lack of awareness in the field of this ecofriendly transport mode. Since dispatchers at logistics service providers and managing clerks at transport departments are often the persons in charge of deciding the transport mode, there is a strong demand for knowledge-generating measures (e.g., workshops, seminars) for people working in the logistics sector.

Active learning is considered as a measure which attracts students' engagement and interest in a topic and thus, recommended by the interviewees. Active learning means students' active involvement - in short: students work on problems on their own. A higher learning success can be realized through the active-involvement of students and diversified lessons or material. Interviewed teachers and university lecturers show a high demand for films, PowerPoint slides, lecture notes and case studies which empower students in active and self-decided learning.

The conducted study and the reviewed literature demonstrate that the connection with the industry is an important issue to meet the requirement of a high-dynamic industry. Thus, lecturers claim for a need to enhanced cross-linking with the industry through field trips, external speakers or realistic case studies (i.e., based on real problems of a company). Indeed, results show evidence that the industry representatives will support the intensified integration of the industry in education through the organization of field trips, provision of real-life case studies and guest lecturers.

Good practice examples in terms of education and knowledge could be identified in the Netherlands, Belgium and Romania, since inland waterway transport presents a high importance for the transport sector and the economy. Moreover, inland navigation is well known to the general pub- 
lic within these countries. Nevertheless, teaching offers and material which deal with the subject of inland waterway and railway logistics are still often missing.

To summarize, there is a high demand for education and training offers across all interviewed stakeholders. In addition, results show a strong evidence for a correlation between the provision of high-quality teaching material and time spent on training concerning eco-friendly transport modes. If high-quality teaching material is available, schools and universities, teachers and lecturers will use these materials for their teaching units. The provision of teaching material and offers (e.g. train-the-trainer workshops, lecture notes, films) will enhance the availability to the essential topic of eco-friendly transport.

Results show that if availability of training offers is presented, teachers and professors will spend more time on education and training regarding eco-friendly transport modes. Moreover the gained knowledge and awareness within the industry will further promote the use of inland waterway transport and therefore improve the modal split towards ecofriendly modes of transport.

Although the authors made every possible effort to be comprehensive in data gathering and to reduce bias that may affect results, this study does suffer some limitations. Due to the fact, that our research sample is limited to the Austrian logistics education sector, some other important aspects may be missing. Moreover, focus groups and personal interviews often stimulate social effects such as group pressure which may bias results.

\section{References}

Directorate General for Mobility and Transport. (2013). Inland waterways. European Commission. Retrieved May 2014 from http://ec.europa.eu/transport/modes/inland/index_en.htm

Dolinsek, M., Hartl, S., Hartl, T., Hintergräber, B., Hofbauer, V., Hrusovsky, M., Maierbrugger, G., Matzner, B., Putz, L.-M., Sattler, M., Schweighofer, J., Seemann, L., Simoner, M., \&Slavicek, D. (2013). Manual on Danube navigation. via donau, Vienna.

European Commission. (2011). White Paper - Roadmap to a single European transport area - Towards a competitive and resource efficient transport system. Brussels. Retrieved from http://ec.europa.eu/transport/themes/strategies/doc/2011_white_paper/white_paper_com\%282011\%29 144 en.pdf

European Commission. (2012). Towards "NAIADES II" promoting, greening and integrating inland waterway transport in the single EU transport area. Brussels.

European Union. (2013). EU energy and transport in figures: 2013 edition. Luxembourg: Publications Office of the European Union.

Eurostat. (2013). Modal split of freight transport. European Union. Retrieved from http://epp.eurostat.ec.europa.eu/tgm/refreshTableAction.do?tab=table\&plugin=1\&pcode=tsdtr220\&lan guage $=$ en

Lancioni, R., Forman, H., \& Smith, M. F. (2001). Logistics and supply chain education. Roadblocks and challenges. International Journal of Physical Distribution \& Logistics Management, 31(10).

Mayring, P. (2010). Qualitative Inhaltsanalyse - Grundlagen und techniken. Weinheim und Basel: Beltz Verlag.

OECD. (2004). Communicating environmentally sustainable transport. The role of soft measures.

Stock, J. R., \& Broadus, C. J. (2006). Doctoral research in supply chain management and/or logisticsrelated areas: 1999-2004. Journal of Business Logistics, 27(1), 139-496.

van Hoek, R. I. (2001). Logistics education: Achieving market and research driven skill development. International Journal of Physical Distribution \& Logistics Management, 31(7/8), 505-519. 
Wrapped in smog - Something in the air? (2013, January 19). The Economist. Retrieved 12 May 2014 from http://www.economist.com/news/china/21569743-measures-air-pollution-go-scale-public-impatience$\underline{\text { rises-something-air }}$

\section{Biographies}

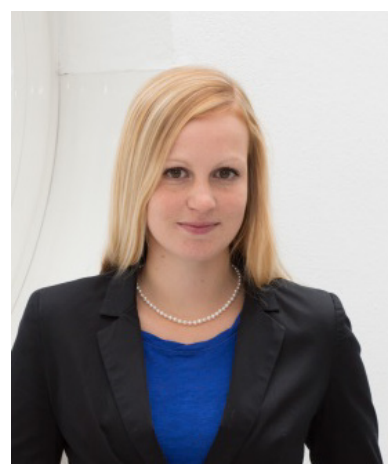

Lisa-Maria Putz (Research Associate): Bachelor Degree in Business Administration, Vienna University of Economy and Business (Austria), Master Degree in SCM University of Applied Sciences Upper Austria (Austria); research and development in Inland Waterway Logistics and Education, project management in national and international projects.

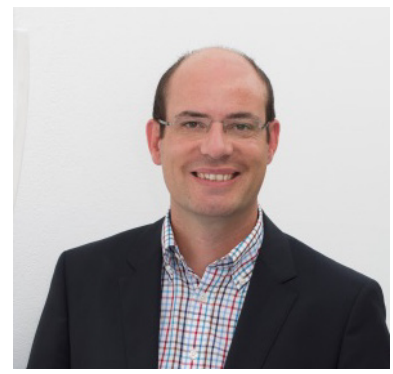

Oliver Schauer (Professor): Doctoral degree in Legal Studies (focus: transport law), Johannes Kepler University Linz (Austria); Post graduate in business administration; research in transport logistics and mobility especially in inland waterway logistics, education and ITS, years of practical experience as manager in logistics companies; native speaker of German, fluent in English. 